\title{
Pemodelan Alokasi Luas Lahan Pada Analisa Highest and Best Use, Lahan di Jl. Kahuripan Raya Kav 30-34 Sidoarjo, Jawa Timur
}

\author{
Angga Hermawan dan Christiono Utomo \\ Jurusan Teknik Sipil, Fakultas Teknik Sipil dan Perencanaan, Institut Teknologi Sepuluh Nopember (ITS) \\ Jl. Arief Rahman Hakim, Surabaya 60111 \\ e-mail: angga.alie13@gmail.com, christiono@ce.its.ac.id
}

\begin{abstract}
Abstrak-Kahuripan Nirwana Village (KNV) merupakan kawasan kota mandiri yang dikembangkan oleh PT Mutiara Mahsyur Sejahtera dengan luas lahan total $375 \mathrm{Ha}$. Hingga tahun 2016 ini baru 83 Ha yang telah dikembangkan menjadi perumahan, area komersial, dan fasilitas pendukung lainnya. Salah satu lahan yang belum dikembangkan adalah lahan seluas 1,28 Ha di Jl Kahuripan Raya Kav 30-34. Guna mendapatkan alternatif terbaik pada lahan tersebut perlu dilakukan sebuah analisa, salah satu yang dapat digunakan adalah analisa Highest and Best Use.

Analisa Highest and Best Use adalah penggunaan terbaik dan tertinggi yang memperhatikan aspek fisik, hukum, serta finansial dalam memperoleh produktivitas maksimum yang dapat menjadi alternatif solusi dari pemecahan masalah pengoptimalan penggunaan lahan di Jl Kahuripan Raya Kav 30-34. Pada aspek fisik analisa HBU ini akan dilakukan pemodelan untuk alokasi luas penggunaan

Hasil penelitian ini didapatkan perpaduan shopping centre dengan apartemen sebagai alternatif penggunaan lahan terbaik dengan nilai lahan tertinggi yaitu sebesar $R p 6.182 .208 / \mathrm{m}^{2}$ dengan produktivitas maksimum sebesar $18,16 \%$
\end{abstract}

Kata kunci-Highest and Best Use,

\section{PENDAHULUAN}

$\mathrm{P}$ T Mutiara Masyhur Sejahtera selaku developer Kahuripan Nirwana Village memiliki lahan total seluas $375 \mathrm{Ha}$ yang akan dikembangkan untuk menjadi kawasan kota mandiri. Hingga tahun 2016 ini baru 83 Ha yang telah dikembangkan menjadi landed house, area komersial, dan fasilitas pendukung lainnya, sedangkan sisanya belum dikembangkan. Salah satu lahan yang belum dikembangkan adalah lahan seluas 2,25 Ha yang terletak di Jalan Kahuripan Raya Kav 30-34. Oleh karena itu pada penelitian ini akan dibahas penggunaan terbaik campuran (mix use) dari lahan tersebut.

Highest and Best Use (HBU), dapat didefinisikan sebagai kemungkinan yang rasional dan sah dari penggunaan tanah atau properti yang sudah dikembangkan secara fisik memungkinkan, mendapat dukungan yang cukup dan secara finansial layak, serta menghasilkan nilai yang tertinggi [1]. Analisa HBU ini merupakan salah satu cara penilaian lahan yang sangat berguna dalam mempertimbangkan peruntukan lahan yang sesuai dan memiliki nilai tertinggi yang mana dalam aplikasinya sudah mulai dipadukan dengan pemodelan alokasi luas lahan.

Pada penelitian ini akan dilakukan pemodelan pada analisa highest and best use untuk menentukan alokasi luas penggunaan yang sesuai aspek hukum, fisik, layak secara finansial serta memiliki produktivitas paling maksimum dengan memperhatikan kendala-kendala yang ada berupa aspek fisik dan hukum.

\section{PENELITIAN TERDAHULU}

Beberapa penelitian terdahulu yang pernah dilakukan sebelumnya tentang Highest \& Best Use (HBU) dikelompokkan menjadi beberapa kelompok berdasarkan persamaannya.

1. HBU Tanah Kosong Penggunaan Single Use

Beberapa penelitian terdahulu yang dilakukan oleh Herradiyanti, Utomo, dan Putri [2], Aziz dan Utomo [3], Faradiany dan Utomo [4], Willyana dan Utomo [5], Kurniawan dan Utomo [6], Rasyid dan Utomo [7], Akmaluddin dan Utomo [8], Anggarawati dan Utomo [9], Mubayyinah dan Utomo [10], meneliti lahan yang berbeda - berbeda namun menggunakan metode analisa Highest and Best Use yang sama, yaitu dengan kondisi tanah kosong atau dianggap kosong dengan alternatif penggunaan berupa single use atau tunggal.

2. HBU Tanah Kosong Penggunaan Mix Use

Beberapa penelitian terdahulu yang dilakukan oleh Mustika dan Utomo [11], Afiata dan Utomo [12], Kasih dan Utomo [13], Utami dan Utomo [14], Mahardika, Nurcahyo, dan Utomo [15], mereka meneliti lahan yang berbeda - berbeda namun menggunakan metode analisa Highest and Best Use yang sama, yaitu dengan kondisi tanah kosong atau dianggap kosong dengan alternatif penggunaan berupa mix use atau campuran.

3. HBU Lahan yang Dikembangkan Penggunaan Mix Use

Penelitian terdahulu yang meneliti peningkatan lahan yang dikembangkan dilakukan oleh Krestian dan Utomo [16], dengan hasil berupa diversifikasi kegiatan pasar Keputran dengan mempertahankan fungsi bangunan berupa mix use building.

4. HBU Tanah Kosong dengan Pemodelan

Beberapa penelitian terdahulu yang dilakukan di Singapura melakukan kajian mengenai penerapan pemodelan pada analisa 
Highest and Best Use Tanah Kosong yaitu Dappah [17] yang melakukan pemodelan berupa program linier untuk menentukan alokasi penggunaan paling optimum yang menghasilkan nilai lahan tertinggi, dimana variabel value diambil dari rata - rata pengunaan sejenis pada pengembangan single use maupun mix use yang telah ditransaksikan dan tercatat di database REALIS milik URA (Urban Redevelopment Authority) Singapura. Selain itu ada Dappah dan Toh [18] yang melakukan perbandingan pemodelan antara program linier dengan program non linier pada analisa Highest and Best Use pada lokasi yang sama pada penelitian Dappah [17].

Penelitian ini memiliki kesamaan mendasar dengan penelitian-penelitian di atas yaitu sama-sama memiliki tujuan untuk mendapatkan keputusan alternatif properti terbaik melalui analisa Highest and Best Use dengan metode yang sama seperti pada kelompok 2 di atas yaitu HBU tanah kosong penggunaan mix use dengan penambahan pemodelan alokasi luas lahan pada aspek fisik seperti yang dilakukan oleh Dappah [17] dalam menentukan komposisi luas dari masing-masing alternatif penggunaannya, namun tidak menggunakan variabel value seperti pada penelitian yang dilakukan Dappah [17].

\section{METODOLOGI}

Penelitian ini menggunakan prinsip penilaian penggunaan campuran (mix use) tertinggi dan terbaik (Highest and Best Use) untuk menghasilkan nilai tertinggi dari lahan Jl. Kahuripan Raya Kav. 30-34. Dengan pemodelan alokasi luas lahan dalam menentukan komposisi luas dari masing-masing alternatif penggunaan pada aspek fisik yang sah secara hukum, layak secara fisik dan finansial serta memiliki produktivitas maksimum tertinggi.

Beberapa rincian pengelompokan indikator dan jenis data yang dibutuhkan dalam penelitian disajikan dalam Tabel 1.

Tabel 1.

Variabel Penelitian

\begin{tabular}{|c|c|c|c|}
\hline No & Variabel & & Klasifikasi \\
\hline 1 & Hukum & $\begin{array}{l}\text { a. } \\
\text { b. }\end{array}$ & $\begin{array}{l}\text { Zoning } \\
\text { Building Code, meliputi : } \\
\text { GSB, KDB, KLB, KDH dan } \\
\text { ketiggian bangunan. }\end{array}$ \\
\hline 2 & Fisik & $\begin{array}{l}\text { a. } \\
b\end{array}$ & $\begin{array}{l}\text { Lokasi lahan \& aksestabilitas } \\
\text { Utilitas Kota,Ukuran \& } \\
\text { Bentuk tanah }\end{array}$ \\
\hline 3 & Finansial & $\begin{array}{l}\text { a. } \\
\text { b } \\
\text { c. }\end{array}$ & $\begin{array}{l}\text { Biaya Investasi } \\
\text { Pendapatan \& Pengeluaran } \\
\text { Aliran Kas }\end{array}$ \\
\hline 4 & $\begin{array}{l}\text { Prod. } \\
\text { maksimum }\end{array}$ & a. & Nilai lahan residual \\
\hline
\end{tabular}

Sumber: Olahan penulis

Proses yang dilakukan dalam penelitian ini adalah sebagai berikut:

\section{Latar Belakang}

1. Penggunaan Lahan di Jl Kahuripan Raya Kav 30-34, Sidoarjo belum opttimal

2. Pemodelan yang pada analisa Highest and Best Use yang dilakukan oleh Dappah dan Toh

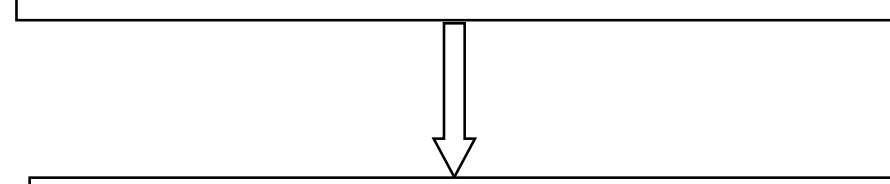

\section{Identifikasi Masalah}

Jenis penggunaan mix use apakah yang mampu memberikan nilai lahan tertinggi pada lahan di Jl.

Kahuripan Raya Kav 30-34

1. Peta Lokasi

2. Peraturan Bangunan

3. Pemilihan alternatif yang akan diuji HBU

4. Dara pembanding aspek finansial properti sejenis

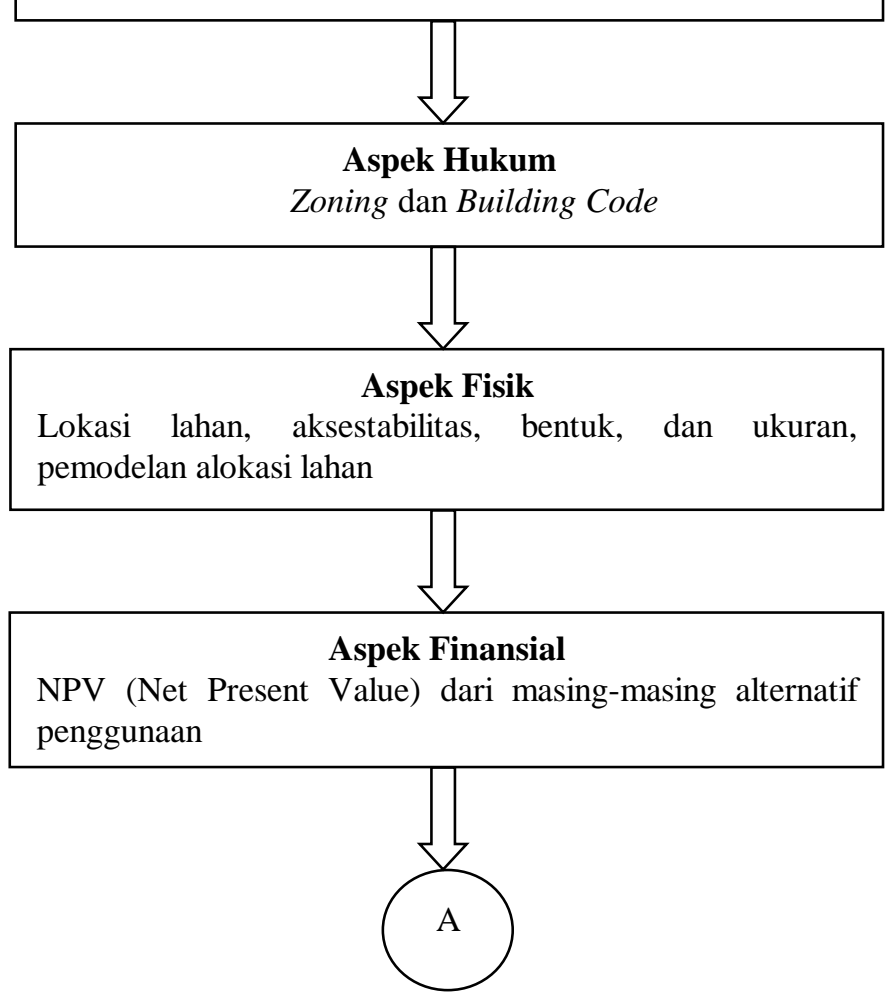




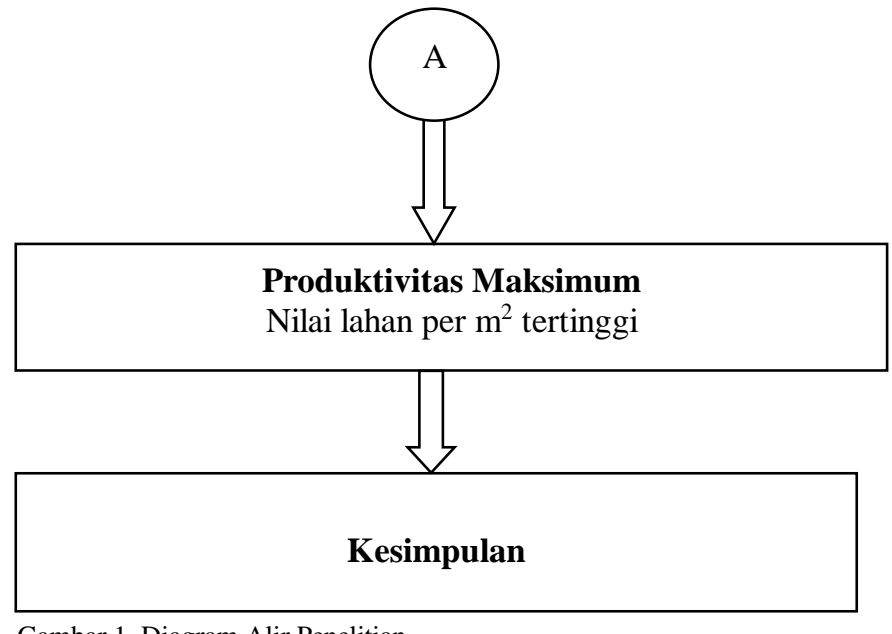

Gambar 1. Diagram Alir Penelitian

\section{ANALISA DAN HASIL}

Pada bab ini akan dibahas tentang hasil penelitian pengunaan properti yang menghasilkan nilai lahan tertinggi dari lahan seluas $12.835 \mathrm{~m}^{2}$ yang terletak di Jl Kahuripan Raya Kav 3034, Sidoarjo.

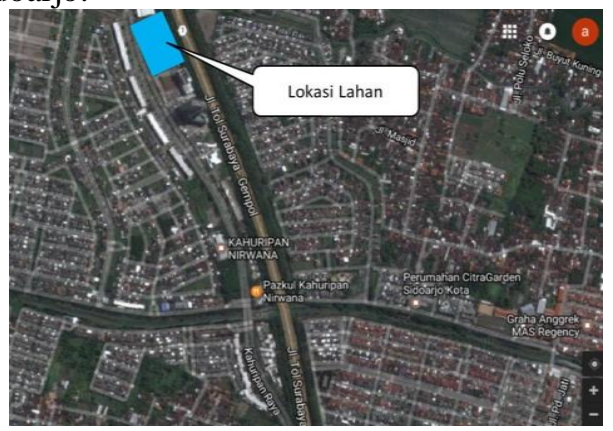

Gambar 2. Lokasi Objek Penelitian

Sumber : googlemaps

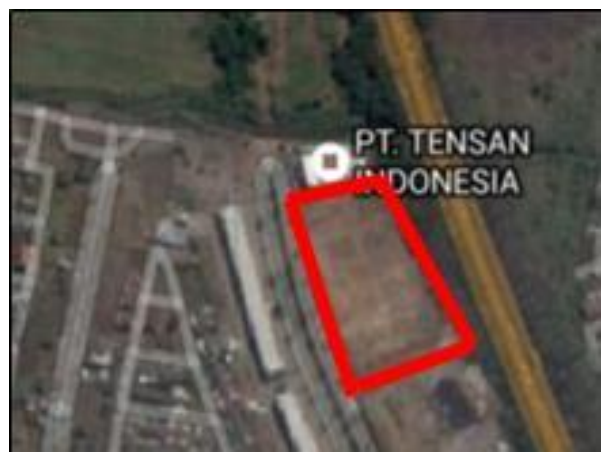

Gambar 3. Bentuk Lahan Objek Penelitian

Sumber : googlemaps

\section{A. Aspek Hukum}

Aspek hukum dipilih sebagai langkah awal, hal ini dilakukan untuk mengetahui penggunaan lahan yang sesuai dengan peraturan pemerintah yang berlaku .

Hasil tinjauan hukum Berdasarkan Perda Kab Sidoarjo No 6 tahun 2009 tentang RTRW Kab Sidoarjo 2009-2029, Perbup No 50 Tahun 2012 tentang Ketentuan \& Tata cara penerbitan persetujuan rencana tapak (site plan), draft RTBL kota baru, penjabaran dari keputusan ditjen perhubungan darat no 72/HK.105/DJRD/96, dan KM No. 5 tahun 2004 tentang

kawasan keselamatan operasi penerbangan di sekitar bandara Juanda menunjukkan bahwa:

1. Objek penelitian berada di kawasan mix use perumahan,perdagangan dan jasa oleh karena itu alternatif penggunaan yang sesuai adalah rumah, apartemen, pertokoan, perkantoran, atau perpaduan antara penggunaan tersebut.

2. Persyaratan Garis Sempadan Bangunan
a. Sisi depan
$: 20 \mathrm{~m}$
b. Sisi belakang $: 25 \mathrm{~m}$
c. Sisi samping kiri $: 8 \mathrm{~m}$
d. Sisi samping kanan $: 8 \mathrm{~m}$
e. Luas GSB
$: 8.730 \mathrm{~m}^{2}$

3. Koefisien Dasar Bangunan (KDB)

$\begin{array}{ll}\text { KDB maksimum } & : 70 \% \times 12.835 \mathrm{~m}^{2} \\ & : 8.984,50 \mathrm{~m}^{2}\end{array}$

4. Koefisien Dasar Hijau (KDH)

KDH Minimum $: 20 \% \times 12.835 \mathrm{~m}^{2}$

$$
: 1.796,90 \mathrm{~m}^{2}
$$

5. Koefisien Lantai Bangunan (KLB)

KLB

6. Rasio Parkir

Rasio parkir

1 SRP

7. Ketinggian Maksimum

Ketinggian maksimum $100 \mathrm{~m}$ atau bila dikonversi menjadi 31 lantai dengan tinggi per lantai 3,1 m

Berdasarkan hasil analisa hukum properti komersial yang dapat dibangun diijinkan memiliki luas lantai dasar maksimum $8.730 \mathrm{~m}^{2}$, ketinggian maksimum 31 lantai, serta luas total lantai terbangun keseluruhan tidak boleh melebihi $64.175 \mathrm{~m}^{2}$ dengan peruntukan antara lain rumah, apartemen, pertokoan, perkantoran, shopping centre, ataupun campuran.

\section{B. Aspek Fisik}

Dalam Aspek fisik dibahas beberapa hal yang meliputi lokasi lahan, ukuran dan bentuk lahan, aksesbilitas ke lokasi dan utilitas, pemilihan alternatif.

1. Analisa Lokasi Lahan

Berdasarkan data yang ada, lahan ini mempunyai lokasi yang cocok untuk properti komersial. Objek terletak di lokasi sentra perdagangan dan fasilitas umum komersial dari perumahan Kahuripan Nirwana seperti pertokoan, perkantoran, apartemen, dan lain-lain. Hal tersebut menunjang pembangunan alternatif objek penelitian.

\section{Analisa Bentuk dan Ukuran Lahan}

Berdasarkan data ukuran lahan yang ada, lahan memiliki luas $12.835 \mathrm{~m}^{2}$, dengan kondisi kavling siap bangun, serta bentuknya yang relatif kotak. Luasan lahan objek penelitian ini menurut Urban land Institute melalui buku Profesional Real Estate Development edisi kedua cocok untuk dijadikan 
properti komersial seperti Shopping centre dan penggunaan mix use properti komersial lainnya.

\section{Analisa Aksesbilitas}

Dari observasi, lokasi di sekitar objek penelitian sudah terbangun jalan utama dari perumahan yang langsung terhubung ke jalan jati raya yang merupakan arteri sekunder, sehingga untuk menghidupkan lahan tidak diperlukan lagi pembangunan akses menuju ke lokasi.

\section{Analisa Utilitas}

Berdasarkan wawancara dan pengamatan, kawasan Kahuripan Nirwana ini telah memiliki ketersediaan utilitas yang memadai. Utilitas yang tersedia antara lain jaringan listrik, air bersih,jaringan air kotor lingkungan dan telepon. Ketersediaan utilitas tersebut dapat memudahkan operasional dari penggunaan lahan tersebut.

\section{Pemilihan Alternatif}

Pemilihan alternatif dilakukan melalui kuisioner yang disebar ke 3 stake holder terkait.Dari kuisioner itu diperoleh alternatif pilihan shopping centre \& hotel, shopping centre \& perkantoran, shopping centre \& apartemen

\section{Alokasi Luas Penggunaan Dalam Properti Mix Use}

Pemodelan program linier terdiri dari fungsi tujuan yang memaksimumkan luas saleable dengan batasan yang dibentuk dari aspek hukum dan panduan perencanaan bangunan komersial. Dengan menggunakan alat bantu software berbasis windows ( $Q M$ for Windows) didapatkan komposisi luasan penggunaan dari masing - masing alternatif sebagai berikut :

Tabel 2.

Hasil Alokasi Luas dengan Program Linier

\begin{tabular}{cccccc}
\hline \hline & & \multicolumn{4}{c}{ Luas Penggunaan $\left(\mathrm{m}^{2}\right)$} \\
No & Alternatif & $\mathrm{x} 1$ & $\mathrm{x} 2$ & $\mathrm{x} 3$ & $\mathrm{x} 4$ \\
\hline 1 & $\begin{array}{l}\text { Shopping Centre } \\
\text { dan Hotel }\end{array}$ & 1.500 & 2.792 & 5.000 & 49.330 \\
2 & $\begin{array}{l}\text { Shopping Centre } \\
\text { dan Perkantoran }\end{array}$ & 1.500 & 2.792 & 5.000 & 48.076 \\
3 & $\begin{array}{l}\text { Shopping Centre } \\
\text { dan Apartemen }\end{array}$ & 1.500 & 2.792 & 5.000 & 47.592 \\
\hline \hline Sumber : Hasil Perhitungan & & & & \\
\hline
\end{tabular}

Dimana :

$\mathrm{z} \quad=$ Luas total dari alternatif penggunaan

$\mathrm{x} 1=$ Luas penggunaan supermarket

$\mathrm{x} 2=$ Luas penggunaan retail

$\mathrm{x} 3=$ Luas penggunaan junior department store

$\mathrm{x} 4=$ Luas penggunaan hotel/kantor/apartemen sesuai alternatif penggunaan

\section{Aspek Finansial}

Analisa finansial meliputi biaya investasi, pendapatan, pengeluaran, dan arus kas terdiskon.

1. Biaya Investasi

Biaya investasi terdiri dari tanah dan biaya bangunan seperti yang terlihat di tabel 3
Tabel 3.

Biaya Investasi

\begin{tabular}{ccc}
\hline \hline No & Penggunaan & Biaya Investasi \\
\hline 1 & Shopping Centre + Perhotelan & Rp495.950.705.880 \\
2 & Shopping Centre + Perkantoran & Rp352.021.387.152 \\
3 & Shopping Centre + Apartemen & Rp413.190.936.592 \\
\hline Sumber : Hasil Perhitungan &
\end{tabular}

\section{Perencanaan Pendapatan}

Perencanaan pendapatan untuk alternatif penggunaan berasal dari penjualan atau penyewaan unit bangunan, service charge dan pendapatan parkir. Tarif tersebut akan direncanakan mengalami kenaikan 5\% tiap 5 tahun sekali.

Tabel 4.

Pendapatan

\begin{tabular}{cccc}
\hline \hline Tahun & Alternatif 1 & Alternatif 2 & Alternatif 3 \\
\hline 2017 & Rp121.567.577.669 & Rp78.642.242.816 & Rp78.867.112.743 \\
2018 & Rp121.567.577.669 & Rp78.642.242.816 & Rp78.867.112.743 \\
2019 & Rp121.567.577.669 & Rp78.642.242.816 & Rp78.867.112.743 \\
2020 & Rp121.567.577.669 & Rp78.642.242.816 & Rp78.867.112.743 \\
2021 & Rp121.567.577.669 & Rp78.642.242.816 & Rp78.867.112.743 \\
2022 & Rp127.645.956.553 & Rp82.574.354.957 & Rp81.181.668.821 \\
2023 & Rp127.645.956.553 & Rp82.574.354.957 & Rp81.181.668.821 \\
\hline \hline
\end{tabular}

Sumber :Hasil Perhitungan

Keterangan tabel

Alternatif 1 : Shopping Centre + Hotel

Alternatif 2 : Shopping Centre + Perkantoran

Alternatif 3 : Shopping Centre + Apartemen

\section{Perencanaan Pengeluaran}

Perencanaan pengeluaran untuk masing-masing jenis alternatif berisikan biaya operasional yang terdiri dari biaya listrik,air,gaji karyawan serta biaya pemeliharan bangunan dan asuransi.

Tabel 5.

Pengeluaran

\begin{tabular}{cccc}
\hline \hline Tahun & Alternatif 1 & Alternatif 2 & Alternatif 3 \\
\hline 2017 & Rp48.200.704.370 & Rp30.165.711.281 & Rp24.543.968.007 \\
2018 & Rp50.444.815.133 & Rp30.947.658.106 & Rp25.325.158.023 \\
2019 & Rp52.574.813.861 & Rp31.714.188.113 & Rp26.079.406.169 \\
2020 & Rp54.704.812.589 & Rp32.480.718.120 & Rp26.833.654.315 \\
2021 & Rp57.327.822.183 & Rp34.056.518.306 & Rp28.131.475.573 \\
2022 & Rp59.457.820.911 & Rp34.823.048.313 & Rp28.885.723.719 \\
2023 & Rp61.587.819.639 & Rp35.589.578.321 & Rp29.639.971.865 \\
\hline \hline
\end{tabular}

Sumber :Hasil Perhitungan

Keterangan tabel

Alternatif 1 : Shopping Centre + Hotel

Alternatif 2 : Shopping Centre + Perkantoran

Alternatif 3 : Shopping Centre + Apartemen 


\section{Analisa Arus Kas}

Pembiayaan untuk investasi pembangunan didapat dari modal sendiri tanpa pinjaman dari bank. Tingkat pengembalian atau MARR (Minimum attractive Rate of Return) didapat dari safe rate atau nilai suku bunga deposito bank ditambah dengan faktor resiko, dalam hal ini developer dianggap termasuk risk averse sehingga nilai faktor resiko diambil lebih kecil dari suku bunga deposito

Tabel 6.

Suku Bunga Deposito

\begin{tabular}{clr}
\hline \multirow{2}{*}{ No } & \multicolumn{1}{c}{ Bank } & \multirow{2}{*}{ Bunga / Tahun } \\
\hline 1 & Bank DBS Indonesia & $6,90 \%$ \\
2 & BNI 1946 & $6,50 \%$ \\
3 & BANK UOB Indonesia & $6,50 \%$ \\
& Suku Bunga Deposito Rata2 & $6,63 \%$ \\
\hline \hline
\end{tabular}

Sumber : Pusat Informasi Pasar Uang (PIPU) Bank Indonesia

MARR $=6,63 \%+4 \%=10,63 \%$

Analisa arus kas dilakukan dengan metode NPV (Net Present Value) yang dilakukan dengan cara mengurangi pendapatan dengan pengeluaran tiap tahun selama masa investasi sehingga didapatkan aliran kas bersih. Arus kas bersih kemudian disesuaikan ditarik ke nilai sekarang dengan mengalikannya ke faktor diskon sebesar tingkat pengembalian yang diinginkan. NPV yang bernilai positif maka dinyatakan layak. Jangka waktu proyeksi arus kas pada shopping centre dan hotel serta shopping centre dengan perkantoran 10 tahun diperoleh dari siklus bisnis, sedangkan untuk apartemen ditentukan 7 tahun sesuai dengan rencana penjualan unit apartemen. Dari analisa arus kas menunjukkan ketiga alternatif penggunaan mix use layak secara finansial.

Tabel 7.

Kelayakan Finansial

\begin{tabular}{|c|c|c|c|}
\hline No & Alternatif & NPV & Kelayakan \\
\hline 1 & $\begin{array}{l}\text { Shopping Centre \& } \\
\text { Hotel }\end{array}$ & Rp 54.170.554.909 & layak \\
\hline 2 & $\begin{array}{l}\text { Shopping Centre \& } \\
\text { Perkantoran }\end{array}$ & Rp 19.110.844.399 & layak \\
\hline 3 & $\begin{array}{l}\text { Shopping Centre \& } \\
\text { Apartemen }\end{array}$ & Rp 17.391.286.095 & layak \\
\hline
\end{tabular}

Sumber : Hasil Perhitungan

\section{Produktivitas Maksimum}

Produktivitas maksimum merupakan penggunaan yang menghasilkan nilai residual yang tertinggi dan konsisten dengan tingkat pengembalian yang dijamin pasar. Nilai properti diperoleh dari Terminal Value di akhir proyeksi arus kas dan nilai lahan diperoleh dari Nilai properti dikurangi biaya bangunan

Tabel 8.

Produktivitas Maksimum

\begin{tabular}{lccc}
\hline \hline Parameter & $\begin{array}{c}\text { Shopping Centre }+ \\
\text { Hotel }\end{array}$ & $\begin{array}{c}\text { Shopping Centre }+ \\
\text { Perkantoran }\end{array}$ & $\begin{array}{c}\text { Shopping Centre }+ \\
\text { Apartemen }\end{array}$ \\
\hline $\begin{array}{l}\text { Nilai } \\
\text { Properti }\end{array}$ & Rp568.145.722.874 & Rp421.659.424.656 & Rp492.539.578.231 \\
$\begin{array}{l}\text { Biaya } \\
\text { Bangunan } \\
\text { Nilai }\end{array}$ & Rp495.950.705.880 & Rp352.021.387.152 & Rp413.190.936.592 \\
Lahan & Rp5.624.855 & Rp5.425.636 & Rp6.182.208
\end{tabular}

\begin{tabular}{lccc}
$\begin{array}{l}\text { Nilai } \\
\text { lahan} / \mathrm{m}^{2}\end{array}$ & Rp5.232.200 & Rp5.232.200 & Rp5.232.200 \\
$\begin{array}{l}\text { Biaya } \\
\text { Tanah } / \mathrm{m}^{2}\end{array}$ & $7,50 \%$ & $3,70 \%$ & $18,16 \%$ \\
\hline \hline
\end{tabular}

Sumber: Hasil Perhitungan

Berdasarkan Tabel 8, nilai lahan tertinggi diperoleh dari alternatif penggunaan mix use antara Shopping Centre dan Apartemen yaitu sebesar $\mathrm{Rp} \quad 6.182 .208 / \mathrm{m}^{2}$ dengan produktivitas tertinggi yaitu sebesar $18,16 \%$.

\section{KESIMPULAN}

Kontribusi dari alternatif penggunaan yang mampu memberikan produktivitas maksimum pada lahan kosong di di Jalan Kahuripan Raya Kav 30-34, Sidoarjo, Jawa Timur adalah alternatif penggunaan mix use antara shopping centre dan apartemen sebesar $18,16 \%$ dengan nilai lahan $6.182 .208 / \mathrm{m}^{2}$, lebih besar dari nilai sebelumnya.

Jadi dapat disimpulkan bahwa peruntukan lahan untuk pengembangan properti shopping centre dan apartemen merupakan alternatif penggunaan terbaik untuk lahan di Jl.Kahuripan Raya Kav 30-34

Pada penelitian ini juga terlihat bahwa bila pemodelan alokasi luas lahan pada analisa HBU, kita hanya memakai constraint atau batasan berupa peraturan tentang batasan ruang menunjukkan hasil guna mencapai pemakaian luas yang maksimum alokasi pemakaian luas terbesar akan diberikan kepada penggunaan yang memiliki indeks luasan efektif paling rendah, hal ini dikarenakan salah satu batasan yang dipakai adalah penyediaan lahan parkir yang dihitung berdasarkan luas efektif dari suatu penggunaan .Semakin besar luas efektif maka semakin besar pula luas parkir yang dibutuhkan sehingga pemakaian luas saleable area tidak mencapai maksimum

\section{DAFTAR PUSTAKA}

[1] A. Prawoto, "Teori dan Praktek Penilaian Properti", BPFE : Yogyakarta, 2003.

[2] M. Afiata dan C. Utomo, "Alternatif Penggunaan Tertinggi dan Terbaik pada Lahan Blauran, Surabaya", Surabaya: Jurnal Teknik ITS Vol. 5, No. 2, D128-D131, 2016.

[3] C.N. Aziz dan C. Utomo, "Analisa Highest and Best Use pada Lahan Gedung Serbaguna Purnama di Jl. R.A. Kartini Bangkalan”, Surabaya: Jurnal Teknik ITS Vol. 4, No. 1, D51-D53, 2015.

[4] F.V. Faradiany dan C. Utomo, "Analisa Highest and Best Use pada Lahan Kosong di Jemur Gayungan II Surabaya", Surabaya : Jurnal Teknik ITS 3 (2), C61-63, 2014

[5] C. Willyana dan C. Utomo, "Analisa Alih Fungsi Pemanfaatan Tertinggi dan Terbaik pada Lahan di Jalan Lowanu Kota Yogyakarta" Prosiding Seminar Nasional Manajemen Teknologi XX hal. B-11-1 s/d B-11-11, 2014

[6] D. Kurniawan dan C. Utomo, "Analisa Penggunaan Tertinggi dan Terbaik pada Aset Milik Pemerintah Terhadap Peningkatan Nilai Lahan Kawasan (Studi Kasus Lahan Sekolah di Koridor Jalan A. Yani Surabaya)". Prosiding Seminar Nasional Manajemen Teknologi XVIII hal. B-22-1 s/d B-22-5, 2013

[7] T.D.A. Rasyid dan C. Utomo, "Analisa Highest and best use (HBU) pada lahan bekas SPBU Biliton", Jurnal Jurusan Teknik Sipil ITS Vol. 2 No. 2 : 2301-9271 D181-D185, 2013.

[8] A. Akmaluddin dan C. Utomo, "Analisa Highest And Best Used Jl. Raya Gubeng No. 54 Surabaya”, Jurnal Jurusan Teknik Sipil ITS Vol. 2 No. 1 : 2301-9271 C6-C10, 2013. 
[9] B. Anggarwati dan C. Utomo, "Analisa Penggunaan Lahan Kawasan Komersial Perumahan Citra Raya Surabaya dengan Metode Highest and Best Use", Surabaya: Jurnal Teknik ITS 2 No.2, D39-D41, 2013

[10] M. Mubayyinah dan C. Utomo, "Analisa Highest and Best Use (HBU) Lahan X Untuk Properti Komersial", Surabaya: Jurnal Teknik ITS Vol. 1, No. 1, hal. D16-D19, 2012

[11] M.S Mustika dan C. Utomo, "Analisa Alternatif Revitalisasi Pasar Gubeng Masjid Surabaya dengan Metode Highest And Best Use", Surabaya: Jurnal Teknik ITS Vol. 5, No. 2, hal. C75-C77, 2016

[12] M. Afiata dan C. Utomo, "Alternatif Penggunaan Tertinggi dan Terbaik pada Lahan Blauran, Surabaya", Surabaya: Jurnal Teknik ITS Vol. 5, No. 2, D128-D131, 2016

[13] R.P.A. Kasih dan C. Utomo, "Analisa Produktivitas Tertinggi dan Terbaik pada Penggunaan Lahan Pasar Genteng Baru Surabaya", Surabaya: Jurnal Teknik ITS Vol. 5, No. 2, hal. D237-D240, 2016

[14] N.P.K. Utami dan C. Utomo, "Analisa Highest adn Best Use pada Lahan Kosong di Kawasan Wisata Ubud", Surabaya: Jurnal Teknik ITS Vol. 4, No. 1, C41-C44, 2015.

[15] M.D.S. Mahardika, C.B Nurcahyo, dan C. Utomo, "Optimasi Penggunaan Lahan Kosong di Kecamatan Baturiti Untuk Properti Komersial Dengan Prinsip Highest and Best Use", Surabaya: Jurnal Teknik ITS Vol. 2, No. 2, hal. D42-D45, 2013

[16] I. Krestian, dan C. Utomo, "Peningkatan Nilai Penggunaan Lahan Pasar Keputran di Kota Surabaya", Prosiding Seminar Nasional Manajemen Teknologi XX hal. B-25-1 s/d B-25-10, 2014

[17] K.A. Dappah, "Highest and Best Use In The Valuation of Mixed-Use Development Sites: Liniear Programming Aprroach", Journal Of Property Research, 2005.

[18] K.A. Dappah dan K.C. Toh, "Non Linear Modelling of The Highest and Best Use In The Valuation of Mixed-Use Development Sites", Singapura: IRES Working Paper Series Vol. 2, p. 3-35, National University of Singapore, 2011. 